MORI, Rafael Cava. Sentir com a inteligência, pensar com a emoção: ciência e tecnologia em canções de Humberto Gessinger. História, Ciências, Saúde - Manguinhos, Rio de Janeiro, v.22, n.3, jul.-set. 2015, p.743-760.

\title{
Sentir com a inteligência, pensar com a emoção: ciência e tecnologia em canções de Humberto Gessinger
}

\section{Feeling with intelligence, thinking with emotion: science and technology in the songs of Humberto Gessinger}

\section{Rafael Cava Mori}

Professor, Universidade Virtual/Universidade de São Paulo (USP). Prefeitura do Campus - USP de São Carlos 13563-120 - São Carlos - SP - Brasil rafael.mori@usp.br

Recebido para publicação em janeiro de 2013. Aprovado para publicação em setembro de 2013.

\section{Resumo}

Este trabalho mapeia as unidades temáticas de ciência e tecnologia nas canções de Humberto Gessinger. Observando a incorporação de palavras e expressões da ciência nessa produção poética, realizamos uma análise de três canções, conforme os estudos do Círculo de Bakhtin. Decorre dessa análise que Gessinger, trazendo tais palavras para a canção popular, faz ressoar nesse gênero ecos dos textos científicos, prosificando sua poesia ao acrescentar-lhe um elemento de "não acabamento". Como para Bakhtin a prosa é mais dialógica e está em maior contato com seu contexto sócio-histórico - comparada com a poesia -, concluímos que Gessinger, ao dispor de palavras e temáticas científicotecnológicas em suas composições, tornase participante ativo dos discursos sobre a pós-modernidade.

Palavras-chave: música; ciência e arte; Círculo de Bakhtin; comunicação e divulgação científica; Brasil.

Abstract

This paper traces the thematic units of science and technology in the songs of Humberto Gessinger. We conducted an analysis of three songs, according to the studies of the Bakhtin Circle, by observing the inclusion of words and expressions of science in this poetic production. It transpires from this analysis that by including these words into popular song, Gessinger brings echoes of scientific texts into this genre, prosifying his poetry by adding an "unfinished" element. Since for Bakhtin prose is more dialogical and is in closer contact with its socio-historical contextcompared to poetry - we conclude that by including scientific-technological words and themes in his compositions, Gessinger becomes an active participant of the discussions about postmodernity.

Keywords: music; science and art; Bakhtin Circle; scientific communication and dissemination; Brazil. 
$\mathrm{H}$ umberto Gessinger é um músico, cantor, compositor e escritor brasileiro, nascido em 1963 em Porto Alegre, cuja carreira se consolidou à frente do conjunto Engenheiros do Hawaii. Esse grupo, considerado um dos representantes de maior sucesso do BRock (designação dos conjuntos brasileiros de rock surgidos na década de 1980, incluindo Legião Urbana, Titãs, Barão Vermelho, entre outros), esteve em atividade entre 1985 e 2008, e produziu 17 discos. Contando sua participação em projetos paralelos - o Humberto Gessinger Trio e o recente Pouca Vogal -, Gessinger contabiliza já vinte álbuns. ${ }^{1}$

Suas composições apresentam peculiaridades que as destacam em relação às de outros cancionistas do rock nacional, e mesmo da música brasileira. Com suas letras repletas de trocadilhos e oximoros, elas não se limitam a tratar de relacionamentos amorosos, apresentando também reflexões sobre o homem contemporâneo. Dapieve (1995, p.145), sobre essas letras, afirma que elas cristalizam "um estilo aforismático, cheio de aliterações, funcional, em que a métrica é importante para segurar o tempo". Tematicamente, "os Engenheiros sempre bateram na mesma tecla, a do sentimento de estranheza de netos de imigrantes diante de sua própria terra. Uma certa náusea sartriana" (p.145).

Essas características têm motivado estudos acadêmicos, destacando-se a dissertação de mestrado de Franz (2007), Mapas do acaso: as canções de Humberto Gessinger sob a ótica contemporânea, na qual afirma ser a produção do músico

o relato de uma geração crescida sob uma cultura de massa assombrada pelo espectro de super-heróis diversos, filmes de ação cada vez mais violentos, videogames em que a luta é mais protagonista que os lutadores, esportes que se tornam cada vez mais radicais. É a sociedade que sofre com a história política do país, que sofre com o excesso de informações e com a solidão das cidades (p.21).

No mesmo trabalho, diversas marcas da pós-modernidade são consideradas recorrentes na obra de Gessinger. Fragmentação, dessubstanciação do eu, crise de identidade, descentralidade, individualismo, estranhamento perante o mundo, descanonização de verdades universais, indeterminação, desconstrução - todas são constantemente aludidas em sua arte. Afinal, as canções de Gessinger ganham vida num momento em que diversos dilemas se põem frente ao homem: retração do sujeito, neutralização do eu e do mundo, efemeridade e frieza nas relações, excesso de informação, solidão, vida surreal e interconversão de realidade e simulacro, para citar alguns.

Além desses aspectos, alguns elementos da produção detêm potencial para despertar a curiosidade de uma plateia específica: os interessados em ciência e tecnologia. Os próprios títulos de algumas canções - "Surfando karmas \& DNA", "Fusão a frio", "Armas químicas e poemas" - sugerem a presença de uma temática científica pontuando as reflexões do compositor sobre a pós-modernidade.

Neste texto, buscaremos revelar como tais unidades temáticas de ciência e tecnologia aparecem incorporadas ao conteúdo poético das canções de Gessinger. Depois, a título de exemplificação, examinaremos algumas canções à luz dos estudos do discurso de Bakhtin e seu Círculo. Com isso, desejamos compreender como se entrelaçam, no interior da criação artística, discursos heterogêneos que, formando híbridos, explicitam a influência recíproca entre a arte e as condições sócio-históricas em que é produzida. No caso de Gessinger, 
buscaremos demonstrar como a incorporação das temáticas científico-tecnológicas em sua criação poética contribui para inseri-la nos discursos sobre a sociedade contemporânea.

A originalidade dessa investigação provém do fato de os estudos linguísticos ou semióticos sobre canções populares brasileiras, em geral, tratarem de compositores como Caetano Veloso e Gilberto Gil, ou movimentos como bossa nova e tropicalismo. Quanto a temas de ciência, Caetano tem sua canção "Livro" (rica em menções à astronomia) dissecada no artigo de Studart (2001); Barros (2008) discorre sobre o disco Quanta (1997) de Gil; e mais recentemente, o trabalho de Gomes e Piassi (2012) se destaca por abordar cancionistas mais diversificados. O rock surge em outro trabalho destes últimos autores (Gomes, Piassi, 2011), a respeito dos temas de astronomia em canções (principalmente internacionais) do fim dos anos 1960, e é caracterizado como um estilo contestador e influente sobre outros aspectos da cultura, como a moda e a publicidade. No contexto internacional, merecem destaque Bucchi e Lorenzet (2008), que investigaram as temáticas de ciência e tecnologia de canções da música pop no período de 1970-1990. Em particular, endossaremos sua perspectiva em considerar a música no quadro mais amplo dos discursos da cultura popular, capaz de gerar "representações, mitos e símbolos" (p.142), ${ }^{2}$ bem como de usar e reinterpretar teorias científicas, campos de pesquisa e artefatos tecnológicos "para construir narrativas sobre o relacionamento dos indivíduos com ciência e tecnologia, e também sobre as relações entre ciência, política e sociedade como um todo" (p.147), "provendo sua audiência com material para interpretar e avaliar sua própria condição e a situação da sociedade" (p.148).

\section{Ciência e tecnologia nas canções de Gessinger}

A busca das unidades temáticas de ciência e tecnologia na obra do cancionista se baseou na análise de conteúdo, técnica descrita por Bardin (2008). Como antecipamos, apresentaremos também uma análise discursiva de algumas canções. A análise de conteúdo, nesse sentido, serviu à organização inicial de um corpus de canções, para uma posterior classificação tipológica. Vale mencionar que a própria Bardin, na obra citada, aposta na complementaridade entre as duas formas de análise, já que "pela sua importância epistemológica e pelo seu interesse na organização dos enunciados de um discurso, [as análises discursivas] só podem ser proveitosas para a análise de conteúdo" (p.274).

Elegemos como unidades de registro substantivos simples e compostos, adjetivos, verbos e locuções que indicassem a presença de uma temática científico-tecnológica: termos do linguajar das ciências naturais (por exemplo, átomo, vírus, poluição, espaço sideral); palavras relacionadas com produtos industriais e aparatos eletrônicos/mecânicos e suas formas de operação (ligo/desligo, antena, carro, piloto automático, satélite); e menções a aspectos da cultura contemporânea relacionados com tecnologias, especialmente as voltadas para a informação e comunicação (filme, TV, manchetes, canção, imagens, walkman).

A unidade de contexto precisou adquirir natureza ainda mais flexível. Ora o contexto que dava significado à unidade de registro era o verso ou a estrofe, ora a própria canção, ora o conteúdo integral do disco em que estava registrada. Duas razões explicam esse caráter inconstante. Primeiro, o fato de a criação artística se expressar, frequentemente, por meio de metáforas. Segundo, por uma idiossincrasia de Gessinger como compositor, que, inspirado pelo 
rock progressivo inglês, concebeu diversos álbuns "conceituais", isto é, aqueles cujas canções são marcadas por grande coesão temática e instrumental. Ouvir um álbum conceitual é estar diante de uma narrativa que se estrutura não só pelo conteúdo das canções, mas também pela forma como são executadas e pela sequência em que as faixas se enfileiram.

Seguimos a ordem de lançamento dos álbuns em que Gessinger atuou como compositor, assim numerados:

(1) Longe demais das capitais (1986)

(2) A revolta dos dândis (1987)

(3) Ouça o que eu digo: não ouça ninguém (1988)

(4) Alívio imediato (1989)

(5) O papa é pop (1990)

(6) Várias variáveis (1991)

(7) Gessinger, Licks \& Maltz (1992)

(8) Filmes de guerra, canções de amor (1993)

(9) Simples de coração (1995)

(10) Humberto Gessinger trio (1996)

(11) Minuano (1997)

(12) ¡Tchau Radar! (1999)

(13) 10.000 destinos: ao vivo (2000)

(14) 10.001 destinos (2001)

(15) Surfando karmas \& DNA (2002)

(16) Dançando no campo minado (2003)

(17) Acústico MTV (2004)

(18) Novos horizontes (2007)

(19) Pouca vogal - Gessinger + Leidencker (2008)

(20) Ao vivo em Porto Alegre (2010)

Todos eles integram a discografia do Engenheiros do Hawaii, exceto o de número 10, do Humberto Gessinger Trio, e os dois últimos, do Pouca Vogal. Cada canção foi identificada por seu número de faixa e pelo número do álbum em que consta. Por exemplo, a canção "Alívio imediato" identifica-se pelos números 4.2, seu registro original (apresentado, portanto, na segunda faixa do quarto disco), e por 8.8 e 18.14, referentes a versões gravadas ao vivo, com letras diferentes em relação à do primeiro registro.

Categorizamos as unidades temáticas conforme a tipologia de Moreira e Massarani (2010) que, apreciando como a ciência e a tecnologia são cantadas pela música popular brasileira, estabeleceram sete categorias de abordagens: (1) canções sobre personalidades do meio científico brasileiro; (2) canções sobre conceitos/teorias científicas; (3) canções que abordam estes conceitos/teorias de modo incidental ou metafórico; (4) canções sobre eventos, como a chegada do homem à Lua; (5) canções sobre impactos da ciência e da tecnologia; (6) sambasenredo sobre ciência e tecnologia; (7) ficções científicas.

Na obra de Gessinger, as categorias presentes são as de número 2, 3, 5 e 7, que receberão os títulos "Reflexões sobre avanços científico-tecnológicos"; "Termos, teorias e conceitos científicos como metáforas"; "O impacto da tecnologia na sociedade contemporânea"; e 
"Ciência, tecnologia e ficção", respectivamente. Ao explorar essas categorias nas próximas subseções, buscaremos, quando possível, relacionar nossos achados com os de trabalhos congêneres e respaldar nossas inferências em afirmações do próprio Gessinger (2009), extraídas de sua autobiografia, Pra ser sincero: 123 variações sobre um mesmo tema, e das crônicas que apresenta em Mapas do acaso: 45 variações sobre um mesmo tema (Gessinger, 2011).

\section{Reflexões sobre avanços científico-tecnológicos}

O avanço científico-tecnológico passa a ser temática recorrente das composições de Gessinger a partir do disco Surfando karmas \& DNA (2002). Mais que acompanhar a popularização de termos como genoma e DNA, a marca dessas canções é problematizar questões controversas numa perspectiva filosófica, às vezes versando sobre questões éticas, outras vezes incorporando discussões da epistemologia moderna.

A biotecnologia - segundo Bucchi e Lorenzet (2008), um subtema de ciência e tecnologia já antecipado pela obra de artistas como o Kraftwerk e Gary Numan, antes mesmo que o advento da clonagem o popularizasse - constitui um exemplo emblemático, explorada explicitamente nas canções "Surfando karmas \& DNA" (15.1) e "Pra quem gosta de nós" (19.6).

A primeira apresenta uma apologia da liberdade, mesmo que condicionada pelos determinantes cármicos e pela genética. Os versos "se eu soubesse antes o que sei agora/ erraria tudo exatamente igual" ecoam os debates sobre as questões éticas envolvidas em possibilidades como as terapias gênicas e a própria clonagem. As promessas desses avanços são repudiadas pelo eu lírico, que descarta o embate com seus condicionantes, preferindo "surfar" as contingências, argumentando: "não quero ter o que eu não tenho / não tenho medo de errar / ... não quero ser o que eu não sou / eu não sou maior que o mar".

Já na outra canção, tudo soa como ameaça: "mapearam o genoma / o acaso vai dançar / sem a senha nem em sonho/impossível disfarçar". Aqui, o mapeamento das sequências do DNA humano aparece como mais uma arma de um sujeito indeterminado, um "eles" já conhecido de canções anteriores, como "Terceira do plural" (15.2): "eles querem te vender, eles querem te comprar / querem te matar (a sede) / eles querem te sedar / quem são eles? / quem eles pensam que são?". No diálogo entre "Pra quem gosta de nós" e "Terceira do plural", associa-se o desenvolvimento biotecnológico aos interesses de poderosos grupos industriais. A humanidade imobilizada pelo controle ideológico e mercê de relações comerciais é exposta em versos aliterantes: "asfaltaram os caminhos / que voltam ao mesmo lugar / sem a senha só em sonho/impossível avançar".

Analogamente, o desenvolvimento tecnológico, desprovido de neutralidade, é alinhado à mercantilização da vida e das escolhas individuais em "Fusão a frio" (16.9): "promessas de fusão a frio, desvio de comportamento / a única escolha que temos é a forma de pagamento".

Já "Além da máscara" (19.1) parece inicialmente explorar as possibilidades que se descortinam com a sucessão de paradigmas científicos: "agora que a terra é redonda / e o centro do universo é outro lugar / é hora de rever os planos / o mundo não é plano, não para de girar / agora que o tempo é relativo / não há tempo perdido, não há tempo a perder". Se a inexistência de verdades universais, de um lado, legitima qualquer projeto, de outro, também mostra seus limites. A inconstância, desfrutada como novidade, logo cede lugar à monotonia: "num piscar de olhos tudo se transforma / tá vendo? já passou! / mas ao mesmo 
tempo / fica o sentimento / de um mundo sempre igual". A rapidez com que se sucedem as descobertas científicas e a alternância paradigmática perdem sua aura de encantamento. Já o verso "a máscara e o rosto trocam de lugar" sugere a influência da ideologia mesmo em questões de ciência.

Finalmente, há "Sei não" (15.8), aberta pelos versos: "não sei qual foi a causa e quais serão as consequências / (a borboleta bate as asas e o vento vira violência)". A dúvida (desconfiança?) expressa pelo título da canção percorre todas as estrofes, entremeada por apenas duas certezas: "o que há de mais moderno/ainda é um sonho muito antigo e o que há de mais seguro também corre perigo". Com o advento da teoria dos sistemas dinâmicos não lineares, fracassou o projeto laplaciano de uma ciência que tudo pudesse prever e controlar, desde que bem estabelecidos os valores iniciais para a multiplicidade de variáveis em estudo. A impossibilidade de medições envolvendo precisão infinita levou ao reconhecimento de que mesmo infinitésimos poderiam influenciar a dinâmica dos sistemas complexos, inviabilizando previsões de longo prazo. A canção, deslocando esses conceitos para o plano dos relacionamentos e das experiências subjetivas, conduz-se por insights que dialogam com outras composições cronologicamente próximas: "não sei a soma exata, só a ordem de grandeza / não sermos literais às vezes faz nossa beleza" são versos que remetem a "Números" (13.16), com sua insistente retórica "e eu, o que faço com estes números?"; e "não sei a quantas anda, é da nossa natureza/não saber o que fazer às vezes faz nossa certeza" traz o ouvinte de volta a "Surfando karmas \& DNA" (15.1), ressonando a filosofia existencialista do verso "na falta do que fazer inventei a minha liberdade". Há um comentário do próprio Gessinger (2009, p.253) a respeito da canção:

Quando a Teoria do Caos ficou pop, com vários livros de divulgação científica falando do assunto, era comum resumi-la dizendo que o bater de asas de uma borboleta na China pode provocar um furacão no Caribe. Há quem se pergunte, nesse caso, que dano causaria o bater de asas de um urubu. O fim do mundo? Não sei quanto o elástico que une causa e consequência pode ser esticado antes de romper-se. Imagino que a toda hora borboletas batam asas na China...

\section{Termos, teorias e conceitos científicos como metáforas}

As canções que mencionam termos típicos do vocabulário das ciências, ou que citam fatos, teorias e conceitos científicos para criar metáforas, começam a constar na discografia de Gessinger a partir dos anos 1990.

"Irradiação fóssil" (10.1) é um rock autobiográfico que traça um paralelo entre a nostalgia de um passado que não volta e a observação de um astro extinto:

eu vi meu próprio corpo como fosse outra pessoa / não me era um corpo estranho visto das alturas / eu estava livre... um corpo em queda livre / (livre) / pra voltar à realidade procurei um rosto amigo / e vi meu próprio corpo como fosse outra pessoa / luz: tempoespaço... como se fosse fácil / como se fosse possível... como se preciso fosse / irradiação (fóssil) / irradiação fóssil / eu estava livre... assim no céu como na terra / (livre) / luz da estrela que não brilha mais / voz de alguém que já não fala mais / eu vejo a luz sem acreditar / que aquela estrela não existe mais / irradiação (fóssil).

Para exagerar o vazio do abandono, "Novos horizontes" (13.18) alinha um fato científico a um sentimento: "corpos em movimento / universo em expansão / o apartamento que era 
tão pequeno / não acaba mais / vamos dar um tempo / não sei quem deu a sugestão / aquele sentimento que era passageiro / não acaba mais". Aqui, o verbo "acabar" se relaciona primeiro com a infinitude espacial, depois a temporal, equiparando o espaço ao tempo e mais uma vez aproximando os universos dos relacionamentos e da ciência.

"Outono em Porto Alegre" (16.11) esboça um quadro de quietude e deleite, até no mundo dos átomos e das moléculas: "nem tudo está perdido / tudo em paz no reino da química / ninguém me telefonou enquanto eu dormia / sonhei com meu pai e ele sorria". Há ainda outras canções que investem no trânsito entre as escalas macro e micro, que analisaremos em uma seção à parte, adiante.

Por ora, vale a pena reproduzir o comentário de Porto (2000, p.32) sobre os conceitos de ciência no poema "Psicologia de um vencido", de Augusto dos Anjos: "O poeta acumula conhecimentos num nível cognitivo consciente - o da ciência - e foi capaz de transmutá-los para um plano diferente, o da expressão lírica, do efeito estético, da emoção". Gessinger faz algo análogo ao empregar palavras típicas da ciência em suas canções, palavras que "conferem aos poemas [canções] musicalidade e ritmo inusitados, por sua própria fonética e estranheza" (p.33).

\section{O impacto da tecnologia na sociedade contemporânea}

Expressões relacionadas com a tecnologia para o combate - bomba(s), arma(s), mira a laser, teleguiada, mísseis, radar(es) - são frequentes nos primeiros discos do Engenheiros do Hawaii, em canções que traduziam a tensão de um cenário em que o conflito nuclear parecia iminente, o que é confirmado por Gessinger (2009, p.176): "Há muitas referências à guerra nas letras dessa fase. $\mathrm{O}$ absurdo acúmulo de armas atômicas e as incertezas do fim da Guerra Fria pintavam muito no rock da época, principalmente inglês". Esse comentário, a propósito, é corroborado pelas análises de Bucchi e Lorenzet (2008). Mesmo sendo palavras típicas de campo lexical da guerra, na obra de Gessinger elas se inserem em campos semânticos não relacionados com os conflitos reais. Metaforizadas, são incorporadas a canções que tratam também de relações de mercado/consumo e relações amorosas/pessoais, conforme demonstra Vieira (2008).

Outras expressões dessa temática são as relacionadas com as mídias em geral, como filmes, comerciais, revistas, outdoors, disco, jingle. Nesse sentido, as tecnologias da informação e da comunicação são analisadas em função dos valores que transmitem e como construtoras de padrões identitários, daí a referência a tribos (beatnik, punk), marcas e produtos associados a um estilo de vida hedonista (Ray Ban, Pierre Cardin, Alfa Romeo, Puma, Coca-Cola, Ferrari), personalidades e grupos musicais tomados como referência comportamental (Duran Duran, John Lennon/Paul McCartney, Pink Floyd/Roger Waters, Willie Nelson, Bob Marley) e nomes de alguns veículos ideológicos (Jornal Nacional, Zero Hora, Diário da Corte, Caras).

Mas no conjunto da obra de Gessinger, um artefato tecnológico em especial recebe destaque. Trata-se do telefone, que marca presença do primeiro disco do Engenheiros do Hawaii ao mais recente.

Em "Eu ligo pra você" (1.3), ele surge incorporado a um dia a dia dominado pela programação alienante da indústria cultural: "eu ligo a TV, desligo a TV e ligo pra você/eu digo 
que consigo, mas não consigo te esquecer". Já a voz que canta "Perfeita simetria" (5.11) deposita no aparelho as últimas esperanças quanto ao fim de sua solidão: "toda vez que toca o telefone / eu penso que é você / toda noite de insônia eu penso em te escrever / pra dizer / que o teu silêncio me agride / e não me agrada / ser um calendário do ano passado". Aqui, a solidão é acompanhada de um alheamento temporal, escancarando a fugacidade do momento presente.

Nessas canções paira a sensação de que, embora o aparelho possa presentificar a voz distante, aproximar as pessoas permanece algo remoto e, mediando quase toda interação social, paradoxalmente, ele apenas reforça o isolamento dos indivíduos numa sociedade em que "Todo mundo é uma ilha" (1.7). Constitui-se, assim, o binômio ligação telefônica-solidão, explicitado em "Vida real" (10.6) ("cai a noite sobre a minha indecisão / sobrevoa o inferno minha timidez / um telefonema bastaria / passaria a limpo a vida inteira / cai a noite sem explicação / sem fazer a ligação"), "9051" (11.7) ("só tenho uma ficha / uma única certeza: / ninguém vai aceitar chamadas a cobrar / ... caiu, a última ficha caiu! / vai cair a ponte! / nós vamos cair no rio! / águas vão rolar, o tempo vai passar / e ninguém vai aceitar chamadas a cobrar") e "Alívio imediato" (18.14) ("não há nada de concreto entre nossos lábios / só um muro de batom e frases sem fim / holofotes nos meus olhos / cegam mais do que iluminam / nem caiu a ficha e já caiu a ligação"). Em "Algo por você" (9.10), a voz que canta aconselha: "hey, garota, não fique esperando o telefone tocar, pois já lhe fizeram sofrer demais / já lhe fizeram feliz demais / tá na hora de você mesma fazer / algo por você / só você pode fazer". E se as relações significativas surgem de encontros autênticos, "Na veia" (16.8) convida: "sem filtro, na veia / vem! / ver com os próprios olhos / vem! / ver a vida como ela é". "Guantánamo" (18.3), por sua vez, pergunta: "quem chama ao telefone? /por que não bate na porta?".

Essas canções nos remetem também ao subtema do simulacro, recorrente em composições mais atuais de Gessinger, como "Na real" (12.9), em que, diante do desaparecimento das fronteiras entre a realidade como ela é e outras realidades (virtuais, artificiais), o sentimento só pode ser de confusão:

olho para o lado e nada vejo / já não sei o que é verdade e o que é desejo / será que você existe? / será fruto da imaginação? / miragens, fantasmas, ovni's / e o que mais for preciso para ser feliz / meu coração visionário tá legal / e dispensa comentários / ele nem pensa na real / será? / miragens, fantasmas, viagens no tempo / será que você existe? / será? / delírio, desejo, vozes e visões / fruto da imaginação?

"Coração blindado" (18.9) ironiza:

fácil achar o caminho a seguir / num mapa com lápis de cor / moleza mandar a tropa atacar / da tela do computador / sem o cheiro / sem o som / sem ter nunca estado lá / sem ter que voltar pra ver o que restou/ com a coragem que a distância dá / em outro tempo em outro lugar / fica mais fácil / ... sempre à distância / sem noção / o que rola pelo chão / não são as peças de um jogo de xadrez.

O mesmo subtema também é captado por Franz (2007); observemos sua análise de "Além dos outdoors" (2.7) ("no ar da nossa aldeia / há rádio, cinema e televisão / mas o sangue só corre nas veias / por pura falta de opção"): 
Observa-se ... a referência ao ambiente como 'aldeia', ideia moderna, que vê o mundo interligado, global, ... onde os indivíduos se identificam em 'tribos', conforme suas aptidões, gostos, interesses comuns e provisórios, cambiáveis.

No ar dessa 'aldeia' nota-se, pelos dois primeiros versos, o boom dos meios de comunicação de massa: 'rádio, cinema e televisão', isto é, a modernidade trouxe um mundo de informações em tempo real para dentro de casa, (de)formando opiniões, mascarando a realidade, criando um ambiente de simulacro ... Embora tenha cada vez mais acesso à informação, menos se vive. Dessa forma, 'o sangue só corre nas veias', isto é, apenas se sobrevive, 'vai se levando', uma vida sem sentido, sem valores, 'por pura falta de opção'. O indivíduo contemporâneo, desta canção, não opta, não escolhe, não se compromete: as circunstâncias que fazem isso por ele (Franz, 2007, p.95-96; destaques no original).

A voz de "Fusão a frio" (16.9) atormenta-se: "ninguém sabe como serão os filhos deste casamento / indústria da informação mais indústria do entretenimento", resumindo o pessimismo do indivíduo desamparado e entregue à realidade em simulacro. Vejamos novamente a análise de Franz (2007, p.32):

Observa-se que, embora o tempo seja sempre o do presente, o que importa não é mais a realidade, mas o seu simulacro; os meios tecnológicos de comunicação [indústria da informação] refazem o mundo a sua maneira, transformando-o em espetáculo [indústria do entretenimento] ... Através do entrelaçamento desses simulacros na vida diária, é possível reunir em espaço e tempo iguais diferentes mundos (de consumo, de mercadorias).

Quanto aos impactos da tecnologia sobre o ambiente, a questão da poluição, que aparecia en passant em canções mais antigas como "Além dos outdoors" (2.7) ("no ar da nossa aldeia / há mais do que poluição / há poucos que já foram / e muitos que nunca serão"), "Desde quando?" (3.5) ("desde quando poluição é progresso? / desde quando progresso é melhor?") e "Pose (anos 90)" (7.6) ("vamos passear depois do tiroteio / vamos dançar num cemitério de automóveis / colher as flores que nascerem no asfalto / ... vamos namorar à luz do polo petroquímico/vamos ficar acima, velejar no mar de lama"), nos anos 2000 acabou merecendo uma canção inteira, "Cinza" (18.8), abordando o aquecimento global:

o mundo é teu / é teu umbigo chapado e aquecido / deve ser o fogo amigo / queimando tudo, joio e trigo / corre mundo um aviso / corre risco teu umbigo / se correr o bicho pega / se ficar corre perigo / bruxas dançam na fogueira / inimigos na trincheira / um calor infernal congela teu sorriso / e o paraíso tropical / sangue, suor e óleo diesel / com limão e muito gelo / arco-íris made in china / de bobeira à beira da piscina / o mundo é teu até o final / pra sempre em tempo real / bruxas dançam na fogueira / inimigos na trincheira / um calor infernal congela o paraíso / o sorriso é glacial / ... bruxas dançam na fogueira / inimigos na trincheira / um calor infernal congela teu sorriso / o paraíso é virtual / corre risco teu sorriso / corre atrás do prejuízo.

\section{Ciência, tecnologia e ficção}

Os exercícios de ficção científica na obra de Gessinger são mais raros. Ainda que "Túnel do tempo" (7.4) e "Canibal vegetariano devora planta carnívora" (7.8) evoquem imagens oníricas com deslocamentos temporais e realidades alternativas, não chegam a se estruturar como narrativas protagonizadas pela ciência e pela tecnologia. 
Chegam mais perto as canções "A conquista do espaço" (7.12) ("passo a passo à eternidade / um passo em falso: a cara no chão / um grande passo pra humanidade / um pequeno veneno pra cada um de nós / - lá do alto deve ser bonito! / - aqui de cima é muito legal..."), um tributo ao chamado space rock justo no disco de Gessinger mais marcado pelo rock progressivo, estilo particularmente rico em visões utópicas e distópicas sobre a exploração espacial (Gomes, Piassi, 2011); e "Nau à deriva" (4.1), essa praticamente uma homenagem ao cinema e aos seriados do gênero:

nau à deriva / no asfalto ou em alto mar / 'perigo, perigo' / perdidos no espaço sideral / apocalipse now / à deriva / talvez um parto / talvez aborto / destroços da nave mãe / ... longe demais / do cais do porto / perto do caos / meu coração é um porta-aviões / perdido no mar esperando alguém pousar / meu coração é um porto sem endereço certo / é um deserto em pleno mar.

Em "A fábula", não registrada em disco, ${ }^{3}$ o ruir de uma sociedade de outro planeta, após um evento cósmico, é narrado por versos fartos em proparoxítonas e alterações prosódicas:

\begin{abstract}
era uma vez um planeta mecânico, / lógico, onde ninguém tinha dúvidas / havia nome pra tudo e para tudo uma explicação / até o pôr do sol sobre o mar era um gráfico / adivinhar o futuro não era coisa de mágico / era um hábito burocrático, sempre igual / explicar emoções não era coisa ridícula / havia críticos e métodos práticos / cá pra nós, tudo era muito chato / era tudo tão sensato, difícil de aguentar / todos nós sabíamos de cor / como tudo começou e como iria terminar/mas de uma hora pra outra, / tudo o que era tão sólido desabou, no final de um século / raios de sol na madrugada de um sábado radical / foi a pá de cal, tão legal / não sei mais de onde foi que eu vim / por que é que estou aqui, para onde eu irei / cá pra nós, é bem melhor assim / desconhecer o início e ignorar o fim / da fábula.
\end{abstract}

\title{
Átomos, partículas e quantum: uma análise bakhtiniana do submicroscópico na obra de Gessinger
}

Após enumerarmos as unidades temáticas de ciência e tecnologia presentes nas canções de Gessinger, apresentaremos uma perspectiva para sua análise. Selecionamos três delas, "Lance de dados" (9.4), "Nem + um dia" (15.6) e "Luz" (18.17), e examinaremos suas incursões ao mundo submicroscópico da matéria, como já foi dito. A escolha dessas canções é fortuita: poderíamos desenvolver o estudo aqui apresentado igualmente com títulos como "Irradiação fóssil" e "Novos horizontes". Apenas preferimos manter-nos próximos de disciplinas como a física subatômica e a química - nossa área de formação - no lugar de versar, por exemplo, sobre astronomia (cujos conceitos aparecem nas duas últimas canções mencionadas).

Adotaremos como referencial os estudos do soviético Bakhtin e de seu Círculo, recorrendo a conceitos-chave como enunciado, palavra, gêneros discursivos, dialogismo, sentido e significado, discurso poético e discurso prosaico. Buscaremos, com essas três canções, observar como a circulação de palavras de um gênero (o dos textos científicos) em outro (a poesia da canção) produz discursos marcados por um hibridismo, o qual exercerá papel importante para situar a obra do cancionista em seu tempo histórico.

Tomemos inicialmente o conceito de enunciado, tratado por Bakhtin/Voloshinov em Marxismo e filosofia da linguagem (Bakhtin, 2004) na década de 1920 e retomado num ensaio 
assinado somente por Bakhtin e escrito entre 1953 e 1954, "Os gêneros do discurso" publicado na coletânea póstuma Estética da criação verbal (Bakhtin, 2011).

Buscando refutar tanto o subjetivismo individualista quanto o objetivismo abstrato no tratamento dos fenômenos da linguagem, Bakhtin/Voloshinov recuperam o caráter ideológico dos signos linguísticos:

não são palavras o que pronunciamos ou escutamos, mas verdades ou mentiras, coisas boas ou más, importantes ou triviais, agradáveis ou desagradáveis etc. 'A palavra está sempre carregada de um conteúdo ou de um sentido ideológico vivencial' (Bakhtin, 2004, p.95; destaques no original).

Essa concepção se opõe tanto à abordagem da língua enquanto emanação da consciência dos sujeitos quanto ao tratamento monológico, em que as condições sócio-históricas que rodeiam o locutor se ausentam de seu discurso. O enunciado é assim "elemento inalienável da comunicação verbal" e, "mesmo na forma imobilizada da escrita, é uma resposta a alguma coisa e é construída como tal. Não passa de um elo na cadeia dos atos da fala" (p.98).

Em "Os gêneros do discurso" (Bakhtin, 2011) o enunciado é apresentado como unidade real da comunicação verbal, em oposição às palavras e orações, unidades convencionais da língua. O que o caracteriza é sua demarcação pela alternância dos sujeitos falantes, ou seja, ele compreende um elemento de acabamento. O término de um enunciado (que já é réplica de um enunciado anterior) solicita uma resposta como um novo enunciado daquele a quem o discurso se dirige - exige dele, pois, uma atitude ativamente responsiva. Daí a natureza dialógica da comunicação.

Brait e Melo (2012), revisando as obras de Bakhtin e seu Círculo, afirmam que o chamado "enunciado concreto", em seus diversos textos e traduções, será "substituído ou fundido na ideia de palavra, de texto, de discurso ... o que não causa nenhum problema à sua compreensão" (p.67). No próprio texto "Os gêneros do discurso" considerações sobre a palavra se integram à teoria do enunciado: "As palavras não são de ninguém, em si mesmas nada valorizam, mas podem abastecer qualquer falante e os juízos de valor mais diversos e diametralmente opostos dos falantes" (Bakhtin, 2011, p.290). Ora, a palavra será a unidade central neste estudo das canções de Humberto Gessinger e, dessa perspectiva, não poderá ser tomada abstratamente: "Só o contato linguístico com a realidade concreta, ... o qual se dá no enunciado, gera a centelha da expressão; esta não existe nem no sistema da língua nem na realidade objetiva fora de nós" (p.292).

Vejamos como isso ocorre nas canções, iniciando com "Lance de dados":

daqui não tem mais volta, pra frente é sem saber / pequenos paraísos e riscos a correr / os deuses jogam pôquer / e bebem no saloon doses generosas de BR 101 / tá escrito há 6 mil anos em para-choques de caminhão / atalhos perigosos feito frases feitas / os deuses dão as cartas... o resto é com você / no fundo tudo é ritmo / a dança foge do salão / invade a autoestrada do átomo ao caminhão / o fim é puro ritmo / o último suspiro é purificação / os deuses dão as costas... agora é só você / os deuses dão as costas... agora é só você... querer.

O devir, o acaso e a indeterminação são temas principais, como se depreende dos primeiros versos. A incerteza do futuro encerra as estrofes em formas quase proverbiais: "os deuses dão 
as cartas... o resto é com você" e "os deuses dão as costas... agora é só você". Na construção da segunda estrofe retrata-se uma realidade num movimento incessante, ainda que regido por uma ordem subjacente, na forma de ritmo e dança.

Consideremos a palavra átomo no verso "invade a autoestrada do átomo ao caminhão". Esse momento da canção explicita possíveis elos com composições anteriores do próprio Gessinger e de outros cancionistas. Por exemplo, a imagem da autoestrada e da BR 101 lembra a evanescência das paisagens da "Infinita highway" (2.3), e que por sua vez cita "As curvas da estrada de Santos" de Roberto Carlos. Já a proximidade de dança e átomo remete à travessia do "Trem das cores" de Caetano Veloso por uma paisagem com elementos naturais de todos os matizes, onde até "os átomos todos dançam".

Em "Lance de dados" o átomo representa o infinitamente pequeno, em oposição às dimensões exageradas de um caminhão. Esse sentido metafórico já aparece referenciado nos dicionários de língua portuguesa, como o Aurélio, que registra o verbete átomo também como "coisa pequeníssima, insignificante, partícula mínima" (Ferreira, 2009, p.224). Em termos dos conceitos de sentido e significado, Bakhtin diria que um sentido concreto e particular, por seu uso reiterado, acabou por se incorporar à própria significação da palavra, que é "por natureza abstrata e tende à permanência e à estabilidade" (Cereja, 2012, p.202). Afinal, toda palavra "é a síntese das práticas discursivas historicamente construídas" (p.204).

Numa outra leitura, a "dança que invade a autoestrada do átomo ao caminhão" não apenas movimenta os corpos em todas as escalas; preenche igualmente todos os domínios da existência, e da metáfora passaríamos à metonímia: o átomo como objeto do saber sistematizado da ciência, e o caminhão como retrato da cotidianidade do senso comum. Ainda como metonímia, átomo e caminhão poderiam ser outros opostos: o conhecimento puro, em si, e o conhecimento aplicado, como artefato tecnológico. Essas leituras se justificam pelo caráter "icônico" de certas imagens da ciência; por exemplo, segundo Myers (1990, p.51), "O modelo atômico de Bohr, com dois ovais que se intersectam encerrando um círculo, tornou-se um ícone que pode representar a energia nuclear, a bomba atômica, ou a ciência moderna em geral".

Mais uma vez, é a singularidade do contexto, a situação sócio-histórica concreta em que os falantes trocam os enunciados, que determinará se esses significados potenciais se converterão em determinados sentidos.

O exemplo de "Lance de dados" explicita também como a natureza dialógica da linguagem permite a circulação de enunciados e palavras por diversos gêneros do discurso, penetrando até em gêneros inusitados. A palavra átomo, signo típico dos enunciados do gênero científico, é transplantada para a canção de Gessinger e, nesse novo ambiente, será não apenas o grão minúsculo que compõe a matéria; terá sua densidade semântica incrementada, enquanto metáfora ou metonímia, para fazer referência à ciência como um todo, ou a um de seus aspectos, a ciência "teórica". Para Bakhtin (2011, p.295),

a expressividade de determinadas palavras não é uma propriedade da própria palavra como unidade da língua e não decorre imediatamente do significado dessas palavras; essa expressão ou é uma expressão típica de gênero, ou um eco de uma expressão individual alheia, que torna a palavra uma espécie de representante da plenitude do enunciado do outro como posição valorativa determinada. 
A relação de estranhamento causada pela palavra científica na expressão poética é levada a um extremo na canção "Nem + um dia", na atmosfera etérea dos versos "boca de extinguir espécies / mãos de acelerar partículas / antenas para radioatividade / olhos de ler código de barras". Como em "Lance de dados", as partículas subatômicas representam aqui o infinitamente pequeno. No entanto, se naquela canção há uma oposição entre escalas na forma de objetos - o átomo e o caminhão -, em "Nem + um dia" a antítese é entre dois processos (observados por campos bem delimitados do conhecimento científico), a extinção de espécies e a colisão de partículas. Os atributos de boca, mãos, antenas e olhos traçam uma caracterização do ser amado, para quem a voz da canção se dirige ao dizer que "não dá mais pra viver sem você / nem mais um dia". Qualificados conforme processos estudados pela ciência - "mãos de acelerar partículas / antenas para radioatividade" -, cria-se um efeito perturbador que realça a singularidade dessa figura, com sua anatomia devastadora em escala macro ("extinguir espécies") ou submicroscópica ("acelerar partículas").

Esses efeitos expressivos não são acidentais, nem obedecem puramente à lógica da métrica e rima. Vejam-se os versos de "Luz": "juntos para sempre / objeto e observador / física moderna / velhas canções de amor / onde estão teus olhos / onde estão teus olhos / sem eles não existo / longe deles nada existe". A própria canção justifica a compatibilidade entre os enunciados científico e poético-musical, fazendo desaparecer o abismo entre um e outro à medida que as oposições substantivas (física/canções de amor) e adjetivas (moderna/velhas) se resolvem com a constatação da inseparabilidade entre objeto e observador, um surpreendente resultado da mecânica quântica.

Podemos conjecturar ao menos um efeito imediato dessa aproximação entre gêneros discursivos tão diferenciados, provocado pela obra de Gessinger. Segundo Bakhtin (2011), a palavra, mesmo como signo ideológico neutro, mantém relações com aqueles enunciados que lhe são típicos, formas composicionais estabilizadas como gêneros do discurso, ao longo da história:

[há] expressões típicas que parecem se sobrepor às palavras. ${ }^{4}$ Essa expressividade típica do gênero não pertence, evidentemente, à palavra enquanto unidade da língua, não faz parte de seu significado mas reflete apenas a relação da palavra e de seu significado com o gênero, isto é, os enunciados típicos ... é o eco da totalidade do gênero que ecoa na palavra ... 'as palavras podem entrar no nosso discurso a partir de enunciações individuais alheias, mantendo em menor ou maior grau os tons e ecos dessas enunciações individuais' (p.293; destaques nossos).

Com base nisso, podemos supor que ecos ou ressonâncias dos enunciados dos textos científicos ainda se fariam ouvir nas palavras oriundas desse gênero, mesmo quando transpostas para outras situações discursivas. Os átomos, as partículas e as suas propriedades quânticas adquirem novos sentidos quando dispostos nos versos cantados, já que passam a nominar sentimentos ou situações dificilmente exprimíveis apenas com um léxico típico da canção popular. Mas tentemos ir além. Recordemos que uma das características do enunciado, enquanto unidade real da comunicação verbal, é a exaustão, o acabamento. O próprio Bakhtin (2011, p.281), entretanto, reconhece que "Nos campos da criação (particularmente no científico, evidentemente), ... só é possível uma única exauribilidade semântico-objetal muito relativa; aqui só se pode falar de um mínimo de acabamento, que permite ocupar 
uma posição responsiva". Se é assim, não estaria Gessinger, ao se apropriar de palavras que fazem referência ao mundo submiscroscópico estudado pela química e pela física, tingindo sua obra artística de um elemento de acabamento apenas "relativo" ou "provisório", típico do caráter evolutivo da ciência?

Essa hipótese adquire maior importância à luz do que Bakhtin define como o texto poético. Segundo Tezza (2010), ele concebe a linguagem poética como portadora de qualidades opostas à prosaica: se esta é dialógica, libertária e em constante interação com seu espaço-tempo, aquela é fechada, centralizadora, dogmática, presa a padrões temáticos, formais e composicionais. Nenhum discurso, apesar disso, pode ser totalmente prosaico ou poético; situa-se num contínuo entre esses dois extremos. E enquanto gêneros, as duas linguagens não estão blindadas de seus condicionantes sócio-históricos, podendo-se afirmar, por exemplo, que a contemporaneidade é prosaica, e contamina a poesia com esse caráter. Assim, se Bakhtin afirma que "No gênero poético (em sentido restrito) ... o discurso satisfaz a si mesmo e não admite enunciações de outrem fora de seus limites" e que "o estilo poético é convencionalmente privado de qualquer interação com o discurso alheio" (citado em Tezza, 2010, p.209), acreditamos ter demonstrado que a obra poética de Gessinger apresenta elementos dialógicos da prosa, pois incorpora palavras típicas de enunciados originados de âmbitos muito característicos e valorizados da contemporaneidade, no caso, a ciência e tecnologia. Tal "prosaísmo" contribui para posicionar essa obra artística enquanto participante ativa dos discursos que atravessam o momento histórico, e não como mera espectadora deles, nem como apenas objeto de contemplação que se erige incorporando o material semiótico ao seu redor. Afinal, como diz Tezza (2010, p.207),

O poético absoluto - que em outros tempos cantava, em formas composicionais congeladas, a grandeza épica dos povos, a iluminação cristã e sua organização de mundo, ou mesmo, mais modernamente, a busca da perfeição estética como sinal de transcendência artística - ficou sem lugar no poema, ou pelo menos manteve-se como expressão desconfortável de um mundo ideológico que não encontra mais eco, cuja voz não encontra auditório disposto a lhe conceder a autoridade da voz.

\section{Considerações finais}

As abundantes canções de Humberto Gessinger com temáticas científico-tecnológicas exemplificam como ciência e arte se podem relacionar de modo produtivo.

Muitos agentes vêm buscando estreitar o contato entre essas duas culturas. A esse res-peito, parafraseamos Moreira (2002, p.17), que assim se expressa sobre a ciência como temática na produção poética: "Ciência e poesia pertencem à mesma busca imaginativa humana, embora ligadas a domínios diferentes de conhecimento e valor. ... A criatividade e a imaginação são o húmus comum de que se nutrem". Reis, Guerra e Braga (2006) traçam um panorama de como os dois campos vêm, desde o Renascimento, fecundando-se mutuamente: da importância de um conhecimento sobre perspectiva para que Galileu interpretasse corretamente suas observações telescópicas, até a incorporação de conceitos da física moderna, como descontinuidade e indeterminação, na pintura contemporânea. "Podemos fazer uma abordagem cultural da ciência e esta poderá nos ajudar a compreendê-la melhor", defendem os autores (p.84). Até 
instituições, em especial os centros e museus de ciências, vêm incentivando esse movimento, como a Fundação Oswaldo Cruz que, em 2002, junto com o Instituto de Ciências Biomédicas da Universidade Federal do Rio de Janeiro, organizou o Primeiro Simpósio sobre Ciência e Arte (Araújo-Jorge, 2004), aglutinando os interesses de sujeitos de diversas regiões do país, empenhados na aproximação entre os dois campos da criatividade humana.

Eu sua autobiografia, Gessinger (2009, p.109) transcreve o seguinte "enunciado", dito em um bate-papo virtual com fãs em 2005: “Semana passada, num show, tocando 'O papa é pop', troquei a frase 'uma palavra na tua camiseta' por 'Che Guevara na tua camiseta'. Putz, ficou muito melhor. Agora [a música] ficou pronta... 15 anos depois de gravar". Essa declaração ajuda a corroborar nossa hipótese lançada sobre a preferência do cancionista por elaborar uma obra com acabamento mínimo, o que ele consegue, além de esculpindo novos versos a cada performance de uma mesma canção, também incorporando enunciados e palavras típicos do gênero científico em seu discurso poético que, assim, adquire uma tessitura prosaica. Sobre esse aspecto, Machado (2012, p.154) faz as seguintes considerações:

Para Mikhail Bakhtin a prosificação da cultura letrada pode ser considerada um processo altamente transgressor, de desestabilização de uma ordem cultural ... Trata-se da instauração de um campo de luta, da arena discursiva onde é possível se discutir ideias e construir pontos de vista sobre o mundo, inclusive com códigos culturais emergentes. Bakhtin alcançou essa outra dimensão da cultura letrada ... examinando a insurreição de uma forma dentro da outra, no mais autêntico processo dialógico. Nela, os discursos e processos de transmissão das mensagens se deixam contaminar, permitindo o surgimento dos híbridos.

Gessinger, aflorando esses híbridos em sua obra como cancionista, instaura o processo dialógico e transgressor no sentido bakhtiniano do termo, pondo-se em contato - ou atrito com os discursos produzidos no mundo a seu redor. O que não deixa de ser o mesmo que diz Zanetic (2006a, 2006b) em sua militância pela aproximação entre ciência e arte. Ao apresentar os chamados "cientistas com veia literária" e os "escritores com veia científica", ele argumenta que "a contaminação mútua entre essas duas culturas é útil não apenas para interpretar o mundo, mas também para transformá-lo" (Zanetic, 2006b, p.57). E se "a capacidade de reflexão e de entendimento do mundo exige que o cidadão domine o discurso da modernidade, e a ciência é um dos pilares mais importantes" (p.47), as canções de Gessinger colaboram para esse fim, pois esse cronista de seu tempo (Franz, 2007), "cancionista com veia científica", constrói uma produção rica em menções a termos e teorias da ciência, além de aplicações tecnológicas, quase sempre mobilizados em prol de uma reflexão crítica sobre as características da pós-modernidade - em especial, o âmbito tecnocientífico.

Nossas conclusões advindas da análise discursiva das canções somam perspectivas para os estudos sobre comunicação pública da ciência. Ainda que não seja intencionalmente dirigido à divulgação científica, o conjunto das canções de Gessinger coloca uma plateia ampla em contato com questões relacionadas com a ciência e a tecnologia, e o próprio cancionista parece reconhecer a importância da aproximação entre campo tecnocientífico (ao mesmo tempo em que "corteja" seu diálogo com arte e poesia) e público em geral:

Numa véspera de voo, fui checar as previsões da meteorologia e li, pela primeira vez, a expressão 'tempo severo'. Estava ilustrada por um desenho de nuvens carregadas. 
Apesar da má notícia, gostei de 'tempo severo'. É sempre bom quando termos técnicos soam poéticos.

Quando perguntam sobre nossos escritores favoritos, geralmente vêm à mente romancistas, poetas ou filósofos. Talvez seja por isso que eu sempre me esqueça de falar dos livros do Stephen Jay Gould. São livros de divulgação científica. Fundamentais para que nós, mortais, tenhamos ao menos uma noção do que se passa lá em cima, na ciência. Ele era paleontólogo e biólogo evolucionista. Fã de beisebol, suavizava seus artigos científicos acrescentando pitadas de esporte, arte e cultura pop. Tribom (Gessinger, 2011, p.74).

Apresentamos, neste texto, uma possibilidade para a análise bakhtiniana, com o olhar sobre a "palavra científica" tomada na concretude dos enunciados, "inoculando" o gênero científico em seu bojo. Examinamos o dialogismo assim disparado, possibilidade prevista por Bakhtin (1981, p.159) em Problemas da poética de Dostoiévski: "as relações dialógicas podem penetrar no âmago do enunciado, inclusive no íntimo de uma palavra isolada se nela se chocam dialogicamente duas vozes". Estudos do processo de divulgação científica à luz dos escritos do Círculo de Bakhtin, aliás, já vêm tomando corpo na literatura, a exemplo dos trabalhos de Grillo (2008, 2009).

Se as canções aqui expostas e analisadas exercem algum papel na divulgação da ciência e na problematização das relações entre ciência, tecnologia e sociedade, caberia também investigar sua integração às situações formais de ensino. Os diversos autores com quem nos deparamos ao estudar o diálogo entre ciência e arte (Moreira, 2002; Moreira, Massarani, 2010; Zanetic, 2006a, 2006b) apostam no potencial das poesias e canções para a educação científica, proporcionando vantagens como a concretização de projetos verdadeiramente interdisciplinares e o aumento da motivação dos estudantes diante de conteúdos considerados ríspidos. Em especial, Zanetic (2006a), citando Ezequiel Theodoro da Silva, lembra que todo professor, independentemente da disciplina que lecione, é um professor de leitura. Disso decorre que as aulas de ciências também são espaços para a (re)leitura, a interpretação e a construção de materiais textuais de gêneros diversos, o que inclui o lirismo expresso em versos, quer acompanhados de melodias, quer não.

A análise do conteúdo musical das canções, que nos escapou aqui, desvelaria ainda outras dimensões dessa aproximação entre ciência e arte. Para Franz (2007, p.23), "todo estudo que leva em consideração apenas a letra da música, sem considerar os elementos musicais, é possível, mas sempre será incompleto. O instrumental, a melodia forma um todo com a letra". Nesse sentido, a semiótica da canção (Tatit, 2007), referencial elaborado para a análise da canção popular brasileira considerando totalidade letra e melodia, pode ser uma opção profícua. Encerramos dando voz, mais uma vez, ao cancionista com veia científica: "não há alternativa / é a única opção / unir o otimismo da vontade / e o pessimismo da razão / contra toda expectativa / contra qualquer previsão / há um ponto de partida / há um ponto de união / sentir com a inteligência / pensar com a emoção ("Esportes radicais" - 15.4).

\section{NOTAS}

1 Desde a época em que este texto foi redigido, a discografia de Humberto Gessinger foi acrescida de mais dois álbuns: Insular (2013) e Insular ao vivo (2014).

${ }^{2}$ Nesta e nas demais citações de textos em outros idiomas, a tradução é livre. 
${ }^{3}$ Trata-se de uma versão para "The logical song", do conjunto britânico Supertramp. Essa letra está disponível no sítio da internet do Engenheiros do Hawaii: http://www2.uol.com.br/engenheirosdohawaii.

${ }^{4}$ Já na tradução de Maria Ermantina Galvão G. Pereira, “as possibilidades de expressões típicas formam como que uma supraestrutura da palavra” (Bakhtin, 1997, p.312).

\section{REFERÊNCIAS}

ARAÚJO-JORGE, Tânia C. (Org.).

Ciência e arte: encontros e sintonias. Rio de Janeiro: Senac Rio. 2004.

BAKHTIN, Mikhail M.

Estética da criação verbal. São Paulo: WMF Martins Fontes. 2011.

BAKHTIN, Mikhail M.

Marxismo e filosofia da linguagem: problemas fundamentais do método sociológico na ciência da linguagem. São Paulo: Hucitec. 2004.

BAKHTIN, Mikhail M.

Estética da criação verbal. São Paulo: Martins Fontes. 1997.

BAKHTIN, Mikhail M.

Problemas da poética de Dostoiévski. Rio de Janeiro: Forense Universitária.1981.

BARDIN, Laurence.

Análise de conteúdo. Lisboa: Edições 70. 2008.

BARROS, Laan M.

Cântico dos quânticos: ciência e arte nas canções de Gilberto Gil. Revista Fronteiras - Estudos Midiáticos, v.10, n.1, p.14-22. 2008.

BRAIT, Beth; MELO, Rosineide de. Enunciado/enunciado concreto/enunciação. In: Brait, Beth (Org.). Bakhtin: conceitos-chave. São Paulo: Contexto. p.61-78. 2012.

BUCCHI, Massimiano; LORENZET, Andrea. Before and after science: science and technology in pop music, 1970-1990. In: Cheng, Donghon et al. (Ed.). Communicating science in social contexts: new models, new practices. New York: Springer. p.139-150. 2008.

CEREJA, William.

Significação e tema. In: Brait, Beth (Org.).

Bakhtin: conceitos-chave. São Paulo: Contexto. p.201-220. 2012.

DAPIEVE, Arthur.

BRock: o rock brasileiro dos anos 80. Rio de Janeiro: Editora 34. 1995.

FERREIRA, Aurélio B.H.

Novo dicionário Aurélio de língua portuguesa. Curitiba: Positivo. 2009.

FRANZ, Jaqueline P.R.

Mapas do acaso: as canções de Humberto

Gessinger sob a ótica contemporânea. Dissertação
(Mestrado em Literatura Brasileira, Portuguesa e Luso-Africanas) - Universidade Federal do Rio Grande do Sul, Porto Alegre. 2007.

GESSINGER, Humberto.

Mapas do acaso: 45 variações sobre um mesmo tema. Caxias do Sul: Belas-Letras. 2011.

GESSINGER, Humberto.

Pra ser sincero: 123 variações sobre um mesmo tema. Caxias do Sul: Belas-Letras. 2009.

GOMES, Emerson F.; PIASSI, Luís P.C.

Visões sobre a astronomia e a natureza em canções da música popular brasileira e suas possibilidades didáticas. Ensino, Saúde e Ambiente, v.5, n.2, p.173-185. 2012.

GOMES, Emerson F.; PIASSI, Luís P.C.

Astros no rock: o discurso sobre a astronomia no rock n' roll e suas possibilidades didáticas. In: Simpósio Nacional de Educação em Astronomia, 1., 2011, Rio de Janeiro. Lista de trabalhos... Rio de Janeiro: Universidade Federal do Estado do Rio de Janeiro. Disponível em: http://snea2011. vitis.uspnet.usp.br/sites/default/files/SNEA2011_ TCO6.pdf.pdf. Acesso em: 1 abr. 2013. 2011.

GRILLO, Sheila V.C.

Dimensão verbo-visual de enunciados de Scientific American Brasil. Bakhtiniana, v.1, n.2, p.8-22. 2009.

GRILLO, Sheila V.C.

Gêneros primários e gêneros secundários no círculo de Bakhtin: implicações para a divulgação científica. Alfa, v.52, n.1, p.57-79. 2008.

MACHADO, Irene.

Gêneros discursivos. In: Brait, Beth (Org.).

Bakhtin: conceitos-chave. São Paulo: Contexto. p.151-166. 2012.

MOREIRA, Ildeu C.

Poesia na sala de aula de ciências? Física na Escola, v.3, n.1, p.17-23. 2002.

MOREIRA, Ildeu C.; MASSARANI, Luisa. La ciencia y la música popular brasileña. Ciencias, n.100, p.68-77. 2010.

MYERS, Greg.

The double helix as icon. Science as culture, v.1, n.9, p.49-72. 1990. 
PORTO, Paulo A.

Augusto dos Anjos: ciência e poesia. Química Nova na Escola, n.11, p.30-34. 2000.

REIS, José C.; GUERRA, Andreia; BRAGA, Marco. Ciência e arte: relações improváveis? História, Ciências, Saúde - Manguinhos, v.13, supl., p.71-87. 2006.

STUDART, Nelson.

Caetano, o quantum de Planck e a expansão do universo. Física na Escola, v.1, n.2, p.23-24. 2001.

TATIT, Luiz.

Semiótica da canção: melodia e letra. São Paulo: Escuta. 2007.

TEZZA, Cristovão.

Poesia. In: Brait, Beth (Org.). Bakhtin: outros conceitos-chave. São Paulo: Contexto. p.197-217. 2010.

VIEIRA, Vinícius B.

Nas roldanas da guerra, uma análise léxicosemântica da engenharia hawaiana. Cadernos do Congresso Nacional de Linguística e Fonologia, v.11, n.11, p.104-114. 2008.

ZANETIC, João.

Física e arte: uma ponte entre duas culturas. ProPosições, v.17, n.1, p.39-57. 2006a.

ZANETIC, João.

Física e literatura: construindo uma ponte entre as duas culturas. História, Ciências, Saúde-

Manguinhos, v.13, supl., p.55-70. 2006b.

\section{REFERÊNCIAS DOS ÁLBUNS ANALISADOS}

ENGENHEIROS DO HAWAII.

Novos horizontes. São Paulo: Universal Music. 2007. 1 CD (18 faixas).

ENGENHEIROS DO HAWAII.

Acústico MTV. São Paulo: Universal Music. 2004. 1 CD (18 faixas).

ENGENHEIROS DO HAWAII.

Dançando no campo minado. Rio de Janeiro:

Universal Music. 2003. 1 CD (11 faixas).

ENGENHEIROS DO HAWAII.

Surfando karmas \& DNA. Rio de Janeiro: Universal Music. 2002. 1 CD (11 faixas).

ENGENHEIROS DO HAWAII.

10.001 destinos. São Paulo: Universal Music. 2001. 2 CDs (26 faixas).
ENGENHEIROS DO HAWAII.

10.000 destinos (ao vivo). São Paulo: Universal Music. 2000. 1 CD (19 faixas).

ENGENHEIROS DO HAWAII.

¡Tchau radar!. Rio de Janeiro: Universal Music. 1999. 1 CD (12 faixas).

ENGENHEIROS DO HAWAII.

Minuano. Rio de Janeiro: BMG Brasil. 1997. 1 CD (12 faixas).

ENGENHEIROS DO HAWAII.

Simples de coração. Los Angeles: BMG Ariola. 1995. 1 CD (11 faixas).

ENGENHEIROS DO HAWAII.

Filmes de guerra, canções de amor. Rio de Janeiro: BMG Ariola. 1993. 1 CD (12 faixas).

ENGENHEIROS DO HAWAII.

Gessinger, Licks \& Maltz. Rio de Janeiro: BMG

Ariola. 1992. 1 CD (12 faixas).

ENGENHEIROS DO HAWAII.

Várias variáveis. Rio de Janeiro: BMG Ariola. 1991. 1 CD (14 faixas).

ENGENHEIROS DO HAWAII.

O papa é pop. Rio de Janeiro: BMG Ariola. 1990.

1 CD (11 faixas).

ENGENHEIROS DO HAWAII.

Alívio imediato. São Paulo: BMG Ariola. 1989.

1 CD (12 faixas).

ENGENHEIROS DO HAWAII.

Ouça o que eu digo: não ouça ninguém. São Paulo: BMG Ariola. 1988. 1 CD (11 faixas).

ENGENHEIROS DO HAWAII.

A revolta dos dândis. São Paulo: RCA. 1987. 1 CD

(11 faixas).

ENGENHEIROS DO HAWAII.

Longe demais das capitais. São Paulo: RCA. 1986.

1 CD (12 faixas).

HUMBERTO GESSINGER TRIO.

Humberto Gessinger Trio. Rio de Janeiro: BMG

Ariola. 1996. 1 CD (12 faixas).

POUCA VOGAL.

Ao vivo em Porto Alegre. Rio de Janeiro: Som Livre. 2010. 1 CD (20 faixas).

POUCA VOGAL.

Pouca Vogal - Gessinger + Leidencker. 2008. 8

faixas no formato mp3. Disponível em: www. poucavogal.com.br. Acesso em: 1 jan.2012.

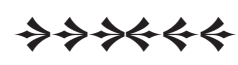

